\title{
IMPLEMENTASI KEBIJAKAN COLLABORATIVE GOVERNANCE DALAM TATA KELOLA KAWASAN PARIWISATA PADA BADAN PROMOSI DAERAH KABUPATEN LOMBOK UTARA
}

\author{
Muhammad Ali', Amil' , dan Zulhadi ${ }^{2}$ \\ ${ }^{1}$ Program Studi Administrasi Publik, Fakultas IImu Sosial dan Ilmu Politik Universitas Muhammadiyah Mataram, \\ 2 Program Studdi IImu Pemerintahan Universitas 45 Mataram \\ khaidirraliihsan@gmail.com , Nadinecallista88@yahoo.com
}

\section{INFO ARTIKEL}

Riwayat Artikel:

Diterima: 15-10-17

Disetujui: $08-11-17$

\section{Kata Kunci:}

Kebijakan

Collaboratif Governace

Sosial ekonomi

\section{A. LATAR BELAKANG}

Indonesia sebagai salah satu negara maritim yang terkenal dengan jumlah pulau yang sangat banyak serta memiliki kearifan lokal yang beragam, merupakan satu potensi yang tidak banyak dimiliki oleh negara lain.

\section{ABSTRAK}

Abstrak: : Sektor pariwsata beberapa dekade terakhir mampu menyumbang pendapatan yang besar terhadap pemasukan kas negara. Dengan berlakunya desentralisasi secara merata di setiap daerah-daerah di Indonesia sehingga daerah diberikan keleluasaan untuk mengurus rumah tangganya sendiri termasuk dalam tata kelola sektor pariwisata. Lombok Utara merupakan salah satu daerah yang saat ini mengalami perubahan dari sektor pariwisata yang sangat menjanjikan untuk peningkatan PAD dan kesejahteraan masyarakat. Metode yang digunakan dalam penelitian ini adalah kualitatif deskriptif, dengan tehnik pengumpulan data mengunakan, wawancara, observasi, studi literatur dan dokumentasi. Dari hasil penelitian menunjukan bahwa: Implementasi kebijakan Kollaboratif Governance dalam tata kelola kawasan pariwisata pada Badan promosi pariwisata daerah mampu memberikan kontribusi yang besar terhadap pengembangan dan kemajuan sektor pariwisata di daerah, kondisi ini dilihat dari jumlah kunjungan dan tamu yang datang dan menginap di hotel yang berkelas hingga hotel kelas melati di Lombok Utara dari tahun ke tahun terus mengalami peningkatan yang drastis, pada tahun 2008 sebesar 64.374 dan pada tahun 2014 sebesar 503.341 kunjungan. Pemberian otonomi kepada Badan Promisi Pariwisata Daerah untuk melakukan promosi pariwisata di daerah sudah sesuai dengan harapan yaitu mampu mengembangkan dan memajukan pariwisata untuk kesejahteraan masyarakat. Salah satu kewenangan tersebut diatur di dalam ketentuan undang-undang No. Tahun 2009 tentang kepariwisataan. Seperti Badan Promosi Daerah mempunyai tugas untuk meningkatkan citra kepariwisataan di Kabupaten Lombok Utara, meningkatkan jumlah kunjungan wisatawan mancanegara dan penerimaan devisa serta melakukan pengalangan dana selain dari APBD. Kedudukan dari Badan Promosi Pariwisata Daerah adalah sebagai mitra kerja pemerintah daerah dalam menyusun dan menetapkan kebijakan strategis promosi pariwisata antara pemerintah pusat dan daerah serta melakukan koordinasi disektor pariwisata.

\section{$--------->---------$}

Sehingga pemerintah sudah mulai berbenah untuk menangkap peluang tersebut.

Keseriusan pemerintah untuk mengembangkan pariwisata sebagai salaha satu sektor unggulan untuk pembangunan nasional terlihat dari Nawacita Presiden Jokowi. Sektor pariwsata beberapa dekade terakhir 
mampu menyumbang pendapatan yang besar terhadap pemasukan kas negara. Dengan berlakunya desentralisasi secara merata di setiap daerah-daerah di Indonesia sehingga daerah diberikan keleluasaan untuk mengurus rumah tangganya sendiri termasuk dalam tata kelola sektor pariwisata.

Sebagai salah satu sector yang dapat menguntungkan bagi pemerintah, pariwisata harus mendapatkan perhatian khsusus dari pemerintah, terutama terkait dengan persoalan promosi dan pengembangan pariwisata yang dari tahun ke tahun terus mengalami peningkatan wisatawan baik lokal maupun Mancan Negara.

Kondisi tersebut harus mampu dimanfaatkan oleh pemerintah dalam rangka meningkatkan promosi kepariwisataan di Indonesia, terutama daerah-daerah pelosok yang masih belum terjangkau dan terjamah oleh tangan manusia, yang keasliannya masih sangat alami, biasanya wisatawan mancan Negara lebih menyukai kondisi yang seperti itu, dari pada obyek wisata yang sudah terjamah oleh manusia.

Banyaknya objek wisata yang masih belum dikenal oleh masyarakat luas, juga menjadi persoalan tersendiri bagi pemerintah dalam rangka memperkenalkan objekobjek wisata yang ada di Indonesia. Masih minimmnya tingakt promosi menjadi kendala pemerintah dalam memperkenalkan pariwisata lokal ke luar negeri, terutama objek wisata yang berada di daerah pelosok yang jauh dari ibu kota dan kota-kota besar lainnya di Indonesia.

Sebagai salah satu daerah otonom baru, pemerintah Kabupaten Lombok Utara, harus lebih giat lagi dalam mempromosikan pariwisata lokal, karena potensi yang dimiliki oleh daerah ini, terutama disektor pariwisata tidak kalah menaruknya dengan daerah-daerah lain di Indonesia. Berikut dapat dilihat abjek wisata yang ada di Kabupaten Lombok Utara:

Tabel 1

Daftar Obyek Wisata Kabupatan Lombok Utara

\begin{tabular}{|c|c|c|c|}
\hline NO & Objek Wisata & Lokasi & Kecamatan \\
\hline $\mathbf{1}$ & Pantai Sengigi & Desa Malaka & Pemenang \\
\hline 2 & Gili Trawangan & $\begin{array}{l}\text { Gili } \\
\text { Trawangan }\end{array}$ & Pemenang \\
\hline 3 & Gili Air & Gili Air & Pemenang \\
\hline 4 & Gili Meno & Gili Meno & Pemenang \\
\hline 5 & Pantai Medana & Desa Medana & Pemenang \\
\hline 6 & Pantai Sire & Desa Sire & Pemenang \\
\hline 7 & PantaiImpos & Desa Sire & Tanjung \\
\hline 8 & Air Terjun Kerta & Desa Kerta & Gangga \\
\hline 9 & Pantai Tebing & Desa Luk & Gangga \\
\hline 10 & Kesenian Sireh & Desa Bentek & Gangga \\
\hline $\mathbf{1 1}$ & $\begin{array}{lr}\text { Kesenian } & \text { Gendang } \\
\text { Belek } & \text { dan } \\
\text { Gambelan } & \end{array}$ & $\begin{array}{l}\text { Semua } \\
\text { Kecamatan } \\
\text { Ada }\end{array}$ & $\begin{array}{l}\text { Kabupaten } \\
\text { Lombok Utara }\end{array}$ \\
\hline 12 & Perisian & $\begin{array}{l}\text { Semua Desa } \\
\text { ada }\end{array}$ & $\begin{array}{l}\text { Kabupaten } \\
\text { Lombok Utara }\end{array}$ \\
\hline 13 & $\begin{array}{l}\text { Air Terjun Senang } \\
\text { Gila }\end{array}$ & Bayan & Bayan \\
\hline 14 & Gunung Rinjani & Bayan & Bayan \\
\hline
\end{tabular}

\section{Di olah dari Berbagai Sumber}

Dari fenomena di atas, seharusnya pemerintah tanggap dengan kondisi daerah yang memiliki potensi besar untuk dikembangkan di sector pariwisata, supaya pariwisata lokal, menjadi terangkat yang nantinya akan berimplikasi pada semakin banyaknya lapangan pekerjaan dan semakin berkurannya tingkat kemiskinan yang ada di Kabupaten Lombok Utara. Karena pada tahun 2011, angka kemiskinan daerah otonom baru ini mencapai $43,14 \%$, angka yang menduduki peringkat terbawah dari 10 Kabupaten dan Kota yang ada di Provinsi Nusa Tenggara Barat. Oleh karena itu, besarnya peluang dari sector pariwisata ini, diharapkan nantinya akan semakin menambah kesejahteraan masyarakat lokal.

Adanya undang-undang NO 10 tahun 2009 tentang Kepariwisataan, Kepres 22 tahun 2011, Kemenpan No 69 tahun 2010. Terbitnya kebijakan pemerintah tersebut merupakan usaha dan ihtiar pemerintah pusat dalam rangka membuka peluang sector pawisata nasional dikembangkan untuk kesejateraan masyarakat. Melalui dasar itulah Kabupaten Lombok Utara membentuk suatu badan yang dinamakan Badan Promosi Pariwisata Daerah. Dimana kewenangan dan tupoksi dari badan ini adalah meningkatkan citra pariwisata daerah melalui berbagai macam kegitan promosi dan iven-iven baik yang bertarap nasional dan bahkan internasional.

Meningkatkan kujungan wisatwan mancanegara dan devisi. Besarnya peluang disektor pariwisata merupakan salah satu daya pikat kenapa sector ini harus dikembangkan dengan baik, selain membuka lapangan pekerjaan baru, pemerintah juga akan mendapatkan devisi dari wisatawan manca Negara. Tanpa menyampingkan peran dari Wisatawan Nusantara, untuk pengembangan pariwisata nasional, pemerintah juga harus memperhatikan promosi ke daerah-daerah tidak hanya melakukan promosi keluar negeri.

Studi ini difokuskan pada sejauhmana implementasi kebijakan Kollaboratif Governance dalam tata kelola kawasan pariwisata pada Dewan Promisi Daerah yaitu Kabupaten Lombok Utara, dalam rangka meningkatkan sektor pariwisata guna meningkatkan kesejahteraan masyarakat melalui daerah. Selain itu juga penelitian ini akan melihat sejauhmana efektivitas keterlibatan unsur non pemerintah dalam menentukan kebijakan pariwisata. Sumber data atau informasi diambil dari beberapa Badan atau Dinas terkait yang ada di Kabupaten Lombok Utara. Selain itu, studi ini juga melakukan pendalaman terhadap situasi dan kondisi obyektif di daerah dengan melakukan wawancara dengan beberapa responden yang telah ditentukan terlebih dahulu

\section{B. METODE PENELITIAN}

Penelitian ini menggunakan pendekatan kualitatif, Dalam pendekatan kualitatif, peneliti berusaha 
mengamati dan mengungkap realitas yang terjadi dilapangan terkait dengan implementasi Kollaboratif Governance Dalam Tata Kelola Kawasan Pariwisata Pada Dewan Promisi Daerah Kabupaten. Tehnik pengumpulan data menggunakan: observasi, wawancara, studi dokumen, dan quisioner. Sedangkan tehnik analisis data dimulai dari: reduksi data, penyajian data, sampai pada verifikasi data dan menarik kesimpulan.

\section{HASIL DAN PEMBAHASAN}

\section{Implementasi Kebijakan Pariwisata Pada Badan promosi Daerah Kabupaten Lombok Utara}

Keberhasilan sektor pariwisata khususnya di Lombok Utara tentunya di tentukan oleh banyak hal seperti, regulasi, SDM dan semua stakholder yang terlibat baik itu secara langsung sebagai pelaku pariwisata maupun masyarakat yang terkenda dampak dari di implementasikannya kebijakan yang terkait dengan pariwisata.

Regulasi yang mengatur terkait dengan pariwisata yang ada di Lombok Utara adalah Peraturan Bupati No. 5 tahun 2015 tentang tata kerja, persyaratan dan tata cara pemberhentian unsur penentu kebijakan BPPD KLU. Dan Keputusan Bupati Kabupaten Lombok Utara No. 217 tahun 2015 tentang penentuan unsur penentu kebijakan BPPD KLU periode tahun 2015-2019. Melalui dasar itulah Kabupaten Lombok Utara membentuk suatu badan yang dinamakan Badan Promosi Pariwisata Daerah dimana kewenagan dan tupoksi dari badan ini adalah meningkatkan citra pariwisata daerah melalui berbagai macam kegiatan promosi dan ivent-ivent yang bertarap nasional maupun internasional.

Kewenangan Badan Promosi Pariwisata Daerah di Dalam Undang-undang No 10 taun 2009 tentang Kepariwisataan terdapat dalam bab x pasal 43-49. Di dalam pasal 43 ayat 1 mengatakan bahwa pemerintah daerah dapat memfasilitasi pemebtukan badan Promosi Pariwisata Daerah yang berkedudukan di Ibu Kota Provinsi dan atau Kabupaten/Kota. Badan Promosi Pariwisata Daerah sebagaimana dimaksud pada ayat (1) merupakan lembaga swasta yang bersifat mandiri. Pembentukan Badan Promosi Pariwisata Daerah sebagaimana dimaksud pada ayat (1) ditetapkan dengan Keputusan Gubenur/Bupati/Wali Kota. Struktur organisasi bada promosi pariwisata daerah tediri atas dua unsur yaitu penentu kebijakan dan unsur pelaksana. Badan Promosi Pariwisata Daerah mempunyai tugas:

a. Meningkatkan citra kepariwisatan Indonesia;

b. Meningkatkan kunjungan wisatawan mancanegara dan penerimaan devisa; c. Meningkatkan kunjungan wisatawan nusantara dan pembelanjaan;

d. Mengalang pendanaandari sumber selain Anggaran Pendapatan dan Belanja Negara dan Anggaran Pendapatan dan Belanja Daerah sesuai dengan ketentuan peratura perundang-undangn;

e. Melakukan riset dalam rangka pengembangan usaha dan bisniskepariwisataan;

f. Koordinator promosi pariwisata yang dilakukan dunia usaha di pusat dan daerah;

g. Mitra kerja pemerintah dan pemerintah daerah.

Di dalam pasal 29 dan 30 Undang-undang Nomor Tahun 2009 tentang kepariwisatan ini juga diatur yang menyangkut masalah kewenangan tentang promosi pariwisata bagi daerah provinsi maupun kabupaten/kota. Berpijak dari perundangundangan tersebut maka pemerintah daerah berwenang melakukan promosi pariwisata.

Berdasarkan Peraturan Bupati No. 5 tahun 2015 tentang tata cara persyaratan, tata cara pengangkatan dan pemberhentian unsur penentu kebijakan badan promosi pariwisata daerah Kabupaten Lombok Utara, pasal 6, bahwa unsur penentu kebijakan Badan Promosi Pariwisata Daerah mempunyai tugas:

a. Menyusun dan menetapkan kebijakan strategis dalam rangka meningkatkan citra kepariwisataan daerah;

b. Menyusun dan menetapkan kebijakan strategis dalam upaya meningkatkan promosi kunjungan wisatawan mancanegara dan penerimaan devisa;

c. Menyusun dan menetapkan kebijakan strategis dalam meningkatkan kunjungan wisatawan nusantaraan dan pembelanjaan;

d. Menyusun dan menetapkan kebijakan strategis dalam menggalang pendanaan dari sumber selain Anggaran Pendapatan dan Belanja Daerah dan;

e. Menyusun dan menetapakn kebijakan strategis terhadap kemungkinan melakukan riset dalam rangka pengembangan usaha dan bisnis pariwisata di daerah.

Badan Promosi Pariwisata Daerah Kabupaten Lombok Utara merupakaan salah satu lembaga yang bergerak disektor kepariwisataan yang tugas dan kewenanganya diatur oleh pemerintah, dalam hal ini adalah tertuang Peraturan Bupati No 5 tahun 2015. Kehadiran badan promosi pariwisata ini diharapkan akan mampu membantu pemerintah untuk memajukan sektor periwisata nasional dan regional di mata dunia internasioanal. Sebagai suatu bandan yang bersifat independent tentunya lembaga pariwisata ini harus mampu melakukan inovasi dan percepatan guna mengembangkan sektor pariwisata nasional dan lokal. Karena manfaat pengembangan 
sektor pariwisata tidak hanya untuk peningkatan pendapatan daerah (PAD) tetapi juga yang paling penting dari suatu pembangunan daerah adalah mampu bermanfaat baik secara tangible dan integible, seperti: bermanfaat dibidang pelestarian alama, bidang pariwisata, bidang ekonomi, dan bidang ketenagakerjaan.

Keberadaan Badan Promosi Pariwisata Daerah adalah untuk membantu pemerintah dalam menjalankan program dan strategi disektor kepariwisataan. Badan Promosi Pariwisata Daerah bekedudukan sebagai mitra kerja pemerintah dalam melakukan promosi kepariwisataan di Kabupaten Lombok Utara untuk mencapai tujuannya yakni:

a. Menyusun dan menetapkan kebijakan strategis dalam rangka meningkatkan citra kepariwisataan daerah;

b. Menyusun dan menetapkan kebijakan strategis dalam upaya meningkatkan promosi kunjungan wisatawan mancanegara dan penerimaan devisa;

c. Menyusun dan menetapkan kebijakan strategis dalam meningkatkan kunjungan wisatawan nusantaraan dan pembelanjaan;

Selain sebagai mitra kerja pemerintah, Badan Promosi Pariwisata Daerah Kabupaten Lombok Utara, juga memiliki fungsi sebagai koodinator pariwisata yang dilakukan dunia usaha baik yang berada di pusat maupun daerah. Sehingga BPPD memiliki tugas yang cukup berat dimana rencana pemerintah daerah mampu untuk mendatangkan wisatawan lebih dari 1.000.000 (satu juta ) orang berkunjung dan menginap di wilayah Kabupaten Lombok Utara. Target yang demikain besar mengharuskan pemerintah daerah dan BPPD sebagai mitra kerja pemerintah, agar tetap terus berinovasi disektor kepariwisataan guna menarik minat wisatawan untuk terus berkunjung ke Lombok Utara.

\section{Implementasi Kebijakan Kolaboratif Governace Dalam penentu Kebijakan Pariwisata Daerah}

Kolaborasi berarti bekerja bersama atau bekerja sama dengan orang lain. Ini menyiratkan baik actor maupun individu, kelompok atau organisasi bekerjasama dalambeberapa

kegiatan. (O'Flynn \& Cinta, 2000); Dalam pemerintahan kolaboratif menurut Ansell dan Gast, sebuah pengaturan yang mengatur satu atau lebih lembaga-lembaga public bersama actor non Negara dan pemangku kepentingan terlibat langsung dalam proses penegambilan keputusan secara kolektif yang bersifat formal, berorientasi consensus, dan musyawarah yang bertujuan untuk membuat atau melaksanakan kebijakan public atau mengelola program public atau asset (Ansell dan Gash, 2007):
Definisi tersebut menekankan pada enam kriteria penting, yaitu:

a. Forum yang diprakarsai oleh lembaga-lembaga public.

b. Peserta dalam forum tersebut termasuk aktor non Negara

c. Peserta terlibat langsung dalam pengambilan keputusan dan tidak hanya berkonsultasi dengan lembaga-lembaga public.

d. Forum secara resmi dislenggarakan dan bertemu secara kolektif.

e. Forum bertujuan untuk membuat keputusan melalui consensus (bahkan jika consesnsus tidak tercapai dalam praktek).

f. Fokus kolaborasi pada kebijakan public atau manajemen public.

Dengan demikian, maka aspek-aspek collaborative pemerintahan menurut Walter dan Petr (2000:495), kolaboratif sebagai kegiatan formal, yang melibatkan kegiatan bersama, struktur bersama dan berbagai sumber daya. Proses model kolaboratif berekembang secara bertahap. Gray merumuskan tiga langkah proses kolaboratif yakni 1. Pengaruh masalah, 2. Penetapan arah, Implementasi. Ansel danGash (2007) menunjukan bahwa proses kolaboratif terbagi atas, 1. Dialog tatap muka 2. Membangun kepercayaan antar pemerintah dan stakeholder 3 . Komitmen dan 4. Adanya pemahaman bersama antara semua pemangku kepentingan.

Merujuk kepada konsep dan teori menurut para ahli di atas, Dalam menjalankan kewenangan dan tugasnya Badan Promosi Pariwisata Daerah Kabupaten Lombok Utara melibatkan berbagai macam unsur yang terdiri dari pelaksana, seperti: pemerintah, asosiasi pariwisata dan profesi, serta akademisi. Berikut dapat dilihat pola hubungan antara ketiga domain dalam Kolaboratif Government dalam penentuan arah kebijakan pariwisata di Kabupaten Lombok Utara :

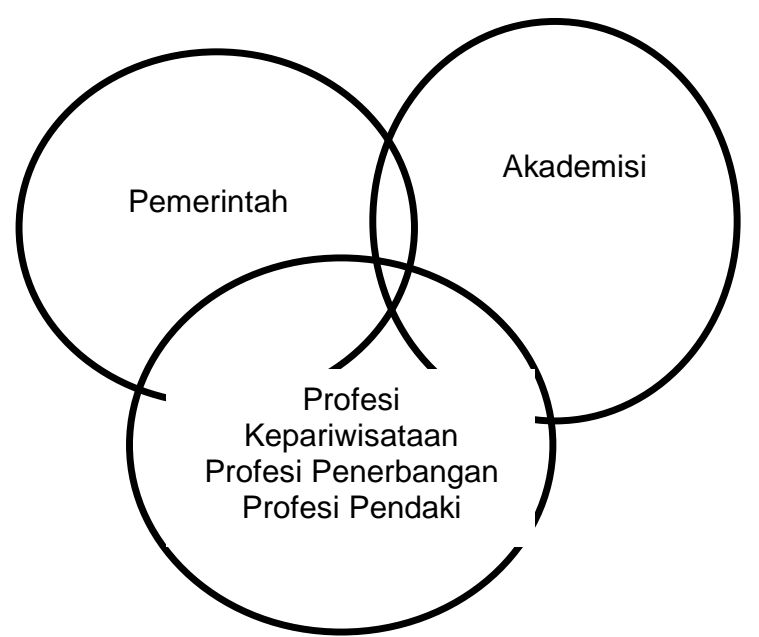

Gambar 1.2 Pola Hubungan Collaboratif Governance dalam Arah Kebijakan Pariwisata di Kabupaten Lombok Utara 
Dalam menjalankan kewenangan dan tugasnya Badan Promosi Pariwisata Daerah Kabupaten Lombok Utara, sudah memiliki tugas dan fungsi masing-masing, mulai dari pemerintah yang mempromosikan pariwisata dari segala hal dan secara umum. Sedangkan untuk Badan Promisi Pariwisata memiliki kewenangan yang sudah ditentukan berdasarkan regulasi yang sudah dibangun dan dibentuk oleh pemerintah. Seperti: Asosiasi Kepariwisataan focus kepada bidang promossi pariwisata, bidang hotel focus pada promosi hotel dan restauran, bidang divinf focus untuk promosi diving, bidang pendakian focus untuk promosi pendakian, dan bidang penerbangan focus untuk informasi penerbangan menuju lokasi wisata yang ada di pulau lombok dan wilayah sekitarnya:

Hasil wawancara dengan Bapak, Ahmad Rifai, Perwakilan dari Asosiasi Kepariwisataan "Gabungan Wisata Bahari Indonesia" (GAWISRI),

"Tugas dan fungsi dari asosiasi kepariwisataan adalah melakukan kegiatan promosi sesuai dengan bidangnyamasing-masing yang ditentukan oleh regulasi pemerintah, seperti:

1. Mempromosikan prospek wisata bahari di wilayah Kabupaten Lombok Utara

2. Wisata Alam, Wisata Selam, divng dll.

Hasil wawancara dengan Bapak, Acerobin , perwakilan dari asosisi kepariwisataan bidang, hotel dan restoran:

"Dimana tugas fungsi dari asosisasi ini adalah memberikan informasi kepada stakholders yang menggunakan jasa kepariwisataan, dan melakukan promosi yang berkaitan dengan fasilitas hotel dan restauran. Informasi yang diberikan seperti: Jumlah hotel, kelas hotel baik itu berbintang maupun kelas hotel melati yang ada diwilayah obyek wisata".

Hasil Wawancara dengan Bapak, Sabarudin selaku perwakilan dari asosiasi kepariwisataan di bidang "Diving" penyelaman, tugas dari asosiasi ini adalah memberikan informasi/ jasa untuk penyelaman.

Hasil wawancara dengan Bapak, Dedi Sudarwanto, perwakilan propesi di bidang penerbangan, memiliki tugas dan kewenangan :

Pertama, mempromiskkan dan memberikan informasi tentang rute-rute penerbangan untuk mencapai lombok untuk mencapai tujuan wisata,

Kedua, Memberikan informasi maskapai yang paling diminati, garuda.

Hasil wawancara dengan Ibu, Ida Nyoman Sudja selaku perwakilan dari Asosiasi instruktur pendakian, memiliki tugas dan wewenang untuk informasi pendakian gunung renjani dan pendakian di wilayah Kabupaten Lombok Utara.

Hasil wawancara dengan Bapak Awaludin, SH.,MH selaku perwakilan dari akademisi,

"Memilik tugas dan wewenang penelitian secara keseluruhan, mengenai wisatawan yang berkunjung ke Kabupaten Lombok Utara; seperti: Asal wisatawan, objek yang diminati, lama tinggal, dan melakukan penelitian dengan pemerintah" Badan Promisi Pariwisata Daerah (BPPD) adalah mitra kerja pemerintah dalam menjalankan setiap kebijakan pemerintah. BPPD dalam menjalankan tugasnya terdiri dari dua unsur, yaitu: penentu kebijakan dan badan pelaksana. Penentu Kebijakan tediri dari anggota BPPD yang di angkat oleh Bupati berdasarkan surat keputusan Bupati. Sedangkan badan pelaksana adalah terdiri dari anggota BPPD dengan susunannya ditentukan oleh Bupati , berdasarkan peraturan Bupati No 5 tahun 2015 tentang tata cara persyaratan pengangkatan dan pemberehentian unsur penentu kebijakan KLU”.

Berdasarkan hasil wawancara dengan beberapa narasumber dari berbagai macam unsur dan perwakilan pariwisata di atas dapat dilihat bahwa pelaksanaan kewenangan dan tugas masing-masing bidang sudah dijalankan oleh Badan Promisi Pariwisata Daerah Kabupaten Lombok Utara. Kondisi tersebut dapat dilihat dari semakin meningkatnya jumlah kunjungan ke Kabupaten Lombok Utara dari tahun ke tahun seperti, tahun 2013 sebesar, 485.870 meningkat menjadi 503.341 pada tahun 2014.

\section{Strategi Badan Promosi Pariwsata Daerah Dalam Meningkatkan Kunjungan Wisatawan \\ Promosi merupakan kegiatan yang di lakukan} oleh pemerintah dalam rangka menarik minat wisatawan domestik maupun mancan negara untuk datang ke Kabupaten Lombok Utara, kegiatan promosi ini di lakukan dengan berbagai cara baik itu melalui media-media maupun secara langsung, kegiatan festival juga tidak jarang dijadikan ajang untuk mempromosikan wisata. Promosi merupakan salah satu dalam menginformasikan kepada orang megenai produk-produk dan menyakinkan para pembeli dalam pasar sasaran suatu perusahaan, organisasi saluran, dan masyarakat umum untuk membeli barang-barangnya (David W. Cravens, 1994:77). Cara-cara dan strategi promosi:

1. Iklan adalah setiap bentuk presentasi dan promosi ide, atau jasa oleh sponsor tertentu. Keuntungan-keuntungan penggunaan iklan untuk berkomunikasi dengan para pembeli diantaranya adalah biaya yang rendah per pemasangan, keragaman, media (Surat kabar, majalah, TV, Radio, pos dan iklan dijalalanan, pengendalian pemasangan, isi pesan yang konsisten dan kesempatan untuk mendesain pesan yang kreatif. Namun iklan juga mempunyai beberapa kelemahan. Ia tidak dapat berinteraksi dengan pembeli mungkin tidak dapat menarik perhatian orang-orang yang melihatnya.

2. Penjualan Langsung "Penjualan langsung adalah persentasi langsung dalam suatu percakapan dengn satu atau lebih calon pembeli, dengan 
maksud untuk mendapatkan penjualan. Pengeluaran tahunan penjualan langsung lebih besar daripada periklanan, barang kali sampai dua kali lipat. Namun kedua komponen ini mempunyai kesamaan dalam beberapa hal, diantaranya menciptakan kesadaran terhadap produk, menyampaiakan informasi dan meyakinkan orang agar mau membeli.

3. Publisitas "publisitas adalah suatu cara merangsang timbulnya permintaan yang bersifat inpersonal terhadap suatu produk, jasa atau ide dengan cara memasang berita komersial di mass media dan tidak dibayar langsung oleh sponsor. Kegiatan-kegiatan hubungan masyarakat dapat memberikan kontribusi yang sangat penting bagi strategi promosi jika kegiatan-kegiatan tersebut direncanakan dan dilakukan untuk mencapau tujuan-tujuan promosi tertentu.

Dalam rangka menarik minat wisatawan untuk tetap berkunjung ke pulau Lombok, Badan Promosi Pariwisata Daerah Kabupaten Lombok Utara, bersama pemerintah terus bergandengan tangan untuk bersinergi memajukan sektor kepariwisataan yang ada di Lombok Utara. Upaya dan strategi tetap dikembangkan seperti; (Program Kerja Bandan Promosi Pariwisata Daerah Kabupaten Lombok Utara, 2016:20-23)

1. Mendata seluruh objek wisata yang ada di wilayah Kabupaten Lombok Utara: Artinya, semua objek wisata harus terdata secara rapi dengan profil dan objek wisata masing-masing, guna mempermudah akses informasi.

2. Membuat Website dan Akun Jejaring Sosial: Website tersebut diberi nama "Pariwisata Lombok Utara" berbagai macam objek wisata yang ada di Kabupaten Lombok Utara terangkum di dalam Website tersebut. Setiap kegiatan bisa langsung di akses melalui link website. Sehingga dengan demikian seluruh pengguna media sosial di seluruh dunia bisa mengakses informasi terkait dengan kepariwisataan yang ada di Lombok Utara.

3. Film Dokumenter: di era globalisasi dan digitalisasi yang paling efektif sebagai bahan promosi pariwista adalah menampilkan film dokumenter dengan sistem digital dengan durasi pendek yang mampu menjadi perhatian para pengunjung.

4. Promosi: dengan menggunakan media seperti:

-North Lombok Travel Fair dilakukan pada tahun 2016

-Festifal Film Dokumenter 2016

- Festival Seni dan Budaya 2016

-Indonesia extreme 2016

-DEMA 2016

-MATTA 2006 dan masih banyak lagi media yang digunakan yang lainnya.
Selain menggunakan media promosi modern seperti, Website dan situs pada media sosial Badan Promosi Pariwisat Daerah Kabupaten Lombok Utara yang bekerjasama dengan pemerintah daerah juga tetap menggunakan media promosi tradisional, seperti;

- Brosur: sebagai media utama pengadaan wisata di Lombok Utara, di situ akan dijelaskan bagaimana peta yang ada dan berbagai kegiatan foto informasi dan lainnya.

- Poster: salah satu media dalam menyampaikan sebuah pesan dalam membentuk visual dan lebih komprehenshif tentang adanya wisata Lombok Utara dan fasilitas yang ada di dalamnya, dimana media poster ini ditempatkan ditempat keramaian.

- Iklam Koran: digunakan karena tingkat penyebaranya yang luas hingga ke luar daerah.

- Kalender: sebagai media promosi pendukung terkait dengan seputar Kabupaten Lombok Utara.

- Majalah: pembuatan majalah yang disebar ke hotel-hotel, travel agent.

X-Banner: di pasang dipusat
pembelanjaan, pertokaan, dan
penyewaan travel.
Spanduk, dan media promosi yang
laainnya.

Upaya dan strategi yang dilakukan oleh Badan Promosi Pariwisata Daerah Kabupaten Lombok Utara yang bermitra dengan pemerintah daerah untuk meningkatkan dan mengembangkan sektor kepariwisataan nasional dan lokal sudah menunjukan hasil dari capaian yang positif. Kondisi tersebut dapat dilihat dari jumlah kunjungan para wisatawan yang berkunjung dan menginap di Lombok Utara terus mengalami peningkatan setiap tahunya. Data menujukan sebagai berikut:

Tabel 1.2

Jumlah kunjungan dan Tamu yang Menginap di Hotel Berbintang, Melati, Losmen, Home Stay di Kabupaten Lombok Utara

\begin{tabular}{l|llll} 
NO & TAHUN & $\begin{array}{l}\text { WISATAWAN } \\
\text { MANCANEGARA }\end{array}$ & $\begin{array}{l}\text { WISATAWAN } \\
\text { NUSANTARA }\end{array}$ & JUMLAH \\
\hline $\mathbf{1}$ & 2008 & 59.253 & 5.019 & 64.374 \\
$\mathbf{2}$ & 2009 & 65.747 & 5.777 & 71.524 \\
$\mathbf{3}$ & 2010 & 189.613 & 38.674 & 228.287 \\
$\mathbf{4}$ & 2011 & 306.136 & 31.511 & 337.646 \\
$\mathbf{5}$ & 2012 & 383.804 & 43.163 & 426.969 \\
$\mathbf{6}$ & 2013 & 433.207 & 52.663 & 485.870 \\
$\mathbf{7}$ & 2014 & 477.797 & 55.554 & 503.341 \\
\multicolumn{2}{l}{ Sumber ; Data Diaspar Kab. Lombok Utara 2015 } \\
\multicolumn{5}{r}{}
\end{tabular}




\section{SIMPULAN DAN SARAN}

\section{Kesimpulan}

Implementasi kebijakan Kollaboratif Governance dalam tata kelola kawasan pariwisata

pada Badan promosi pariwisata daerah mampu memberikan kontribusi yang besar terhadap pengembangan dan kemajuan sektor pariwisata di daerah, kondisi ini dilihat dari jumlah kunjungan dan tamu yang datang dan menginap di hotel yang berkelas hingga hotel kelas melati di Lombok Utara dari tahun ke tahun terus mengalami peningkatan yang drastis, pada tahun 2008 64.374 dan pada tahun 2014503.341 kunjungan. Pemberian otonomi kepada Badan Promisi Pariwisata Daerah untuk melakukan promosi pariwisata di daerah Kabupaten Lombok Utara sudah sesuai dengan harapan yaitu mampu mengembangkan dan memajukan pariwisata untuk kesejahteraan masyarakat. Salah satu kewenangan tersebut diatur di dalam ketentuan undang-undang No. Tahun 2009 tentang kepariwisataan. Seperti Badan Promosi Daerah mempunyai tugas untuk meningkatkan citra kepariwisataan di Kabupaten Lombok Utara, meningkatkan jumlah kunjungan wisatawan mancanegara dan penerimaan devisa serta melakukan pengalangan dana selain dari APBD, sesuai dengan ketentuan perundang-undangan. Kedudukan dari Badan Promosi Pariwisata Daerah adalah sebagai mitra kerja pemerintah daerah dalam menyusun dan menetapkan kebijakan strategis promosi pariwisata antara pemerintah pusat dan daerah serta melakukan koordinasi disektor pariwisata.

\section{Saran}

a. Dalam melaksanakan tugas dan kewenangan sebagai Badan Promosi Pariwisata daerah sebaiknya lebih banyak melakukan kerjasamakerjasama dan koordinasi dengan instansi terkait seperti, dinas Pariwisata Daerah Kabupaten Lombok Utara, beserta jajaranya.

b. Selain itu Badan Promosi Pariwisata Daerah Lombok Utara juga harus berkoordinasi dengan dinas pariwisata provinsi Nusa Tenggara Barat, dan Badan Promosi Pariwisata Provinsi BPPD NTB.

c. Meningkat kinerja yang sudah ada untuk kemajuan dan pengembangan sektor pariwisata yang ada di Kabupaten Lombok Utara.

d. Perlu ada Peraturan Daerah tentang Pariwisata.

\section{DAFTAR PUSTAKA}

[1]. Adisasmita, Rahadjo, Manajemen Pemerintahan Daerah, Graha Ilmu, 2011.

[2]. Arikunto, Suharsimi, Metodologi Penelitian Suatu Pendekatan Praktik, Jakarta: Rineka Cipta, 2010.

[3]. Ansell, Chris \& Alison Gash. Collaborative Governance in Theory and Practice, Journal of Public Administration Research \& Theory (OxfordUniversity Press), 2007.

[4]. Abdul Wahab, Solichin, Analisis Kebijaksanaan: Dari Formulasi ke Implementasi Kebijaksanaan Negara, Jakarta: Bumi Aksara, 2004.

[5]. Budiadjo, Miriam, Dasar-dasar Ilmu Politik, Kompas Gramedia, 2012

[6]. Jurnal Ilmu Pemerintahan dan Kebijakan Publik, Vol.3 No1 Februari 2016, Giat Tri Sambodo, Pelaksanaan Collaborative Governance di Desa Budaya Brosot, Galur Kulon Progo Daerah Istimewa Yogyakarta, 2016.

[7]. Maleong, Lexy, Penelitian Kualitatif, Jakarta: PT. Rineka Cipta, 2010.

[8]. Nurcholis, Hanif, Teori dan Praktik Pemerintahan dan Otonomi Daerah, Grasindo,2007.

[9]. Nugroho, Riant, Kebijakan Publik Formulasi, Implementasi dan Evaluasi, PT Elex Media Kompotindo Kelompok Gramedia, 2003.

[10]. Pasolong, Harbani, Teori Administrasin Publik, Alfabeta, 2013.

[11]. Subarsono, Analisis Kebijakan Publik, Konsep Teori dan Aplikasi, Pustaka Pelajar, 2010.

[12]. Waluyo, Manjemen Publik, Konsep, Aplikasi dan implementasinya Dalam Pelaksanaan Otonomi Daerah, 2007.

[13]. Winarno, Budi , Teori dan Proses Kebijakan Publik, Yogyakarta: Media Press, 2005.

[14]. William. Dunn, Pengantar Analisis Kebijakan Publik, Gadjah Mada University Press, 2003. 